\title{
МОРФОСИНТАКСИЧКЕ СЛИЧНОСТИ И РАЗЛИКЕ У ДВА СРПСКА ИДИОЛЕКТА ИЗ МАЛОГ ГАЈА (У РУМУНИЈИ) И ВЕЛИКОГ ГАЈА (У СРБИЈИ)**
}

\begin{abstract}
У раду се, на основу два идиолекта (МГ1932 и ВГ1922), утврђују морфосинтаксичке сличности и разлике (3. л. мн. презента, през. гл. типа добијем, градња футура 1, аналитизам у деклинацији, замена падежа правца и места, удвојен објекат и ред речи) настале успостављањем државне границе између Малог Гаја (у Румунији) и Великог Гаја (у Србији). Оба идиолекта припадају мешаним или прелазним говорима у којима се срећу особине смедеревско-вршачког и шумадијско-војвођанског дијалекта. Очекујемо да су се у оба идиолекта очувале неке заједничке црте у приближно истом односу (најчешћи је аналитички футур 1, доследно се користи -y код гл. VII и VIII врсте: носу, држу), али и да су у оном из МГ боље очуване дијалекатске особине (-ду; добим;) и да је у њему очигледнији утицај румунског језика и његовог банатског дијалекта (не ти купим машину, јел ти ниси ожењен (нећу ти купити ауто); сад нема те конце; сира од овце; сам ишла у цркви; не се види; мене ми било жао; сина сам га родила; имамо каце велике; Ће да ти продам; који су имали децу, су отишли по вароши, су остали само они стари; метем у лонац $и$ ce кува, a ce кува мало да спадне).
\end{abstract}

Кључне речи: дијалектологија, шумадијско-војвођански, смедеревско-вршачки дијалекат, морфосинтакса, индекс фреквенције.

\section{1. Увод}

После 1918. године успостављена је нова гранична линија са Румунијом, те је велики број српских села остао на румунској страни. Тако је нова граница раздвојила два суседна села, Мали Гај (Румунија) и Велики Гај (Србија)ํ.

*zarko.bosnjakovic@gmail.com

** Рад је настао у оквиру пројекта Дијалектолошка истраживања српског језичког простоpa (148001), који финансира Министарство просвете, науке и технолошког развоја Републике Србије.

${ }^{1}$ О њиховој близини прича наша информаторка (ДС 1932): - А где си рођена? У Мали Гај. -То је овде (близу села Манастир, где се удала 1948), је л тако? - Да, кад се дође, Велики Гај 
Говори ових села могу се означити као прелазни будући да имају особине и смедеревско-вршачког и шумадијско-војвођанског дијалекта (Живковић 1976: 274-275; Живковић/Берић/Веску 1961: 79; Ивић 2009: 102). Говор Малог Гаја је документован теренским записима (Бошњаковић/Радовановић 2009: 161-178) уз који следе кратке напомене о језичким цртама. Такође, анализирано је старо и ново у прозодији Малог Гаја, али је и прозодија тог говора упоређена са оном у Великом Гају да би се видело колико је државна граница утицала на промене у акцентуацији. ${ }^{2}$

Овом приликом поредимо два идиолекта ${ }^{3}$ на морфосинтаксичком нивоу (3. л. мн. презента, презент гл. типа добијем, градња футура 1, аналитизам у деклинацији, замена падежа правца и места, удвојен објекат и ред речи). Њиховим поређењем уочене су неке сличности, али и квантитативне разлике. Такође је уочено да су у идиолекту из Малог Гаја конзервисане неке старије дијалекатске црте, али и да су настале нове под утицајем румунског језика.

Будући да оба идиолекта имају исти инвентар дијалекатских особина, а да су разлике углавном квантитативне природе, морали смо вршити тоталну ексцерпцију примера и потом израчунавати индекс њихове фреквенције. На овај начин су измерене интраговорничке и интерговорничке разлике. Због ограниченог простора, навешћемо само по неколико примера за сваку појаву. За ову врсту истраживања акценат није релевантан, те смо примере наводили без њега.

\section{2. Анализа грађе}

\section{3. л. мн. презента}

1. У оквиру 3. л. мн. презента анализираћемо употребу наставка -ду, али и наставке код гл. VI (-ajy/-ay/-y), VII и VIII (-y/-e) Белићеве глаголске врсте.

1.1. У 3. л. мн. презента свих глаголских врста може се јавити факултативно и наставак -ду, који се додаје на презентску основу (дођеду, пукнеду, кажеду, имаду, мислиду, оћеду). Утврдили смо да је он знатно чешћи у идиолекту из МГ (38 примера или 65,51\%) за разлику од стања у ВГ (14 примера или 22\%), у којем је под утицајем српског стандарда дошло до његовог по-

и Мали Гај су јено нуз друго. Само један шамац и не знам колко, јено два-три километара нас растаје од... (Бошњаковић/Радовановић 2009: 164).

${ }^{2}$ Први рад ће бити објављен у часопису Исходишта (4) посвећеном проф. др Михају (Миљи) Н. Радану, а други у зборнику радова са научног скупа Материјална и духовна култура Срба у мултиетничким срединама и/или периферним областима који је одржан у Темишвару од 18. до 21. октобра 2018.

${ }^{3}$ Прва информаторка је рођена 1932. у Малом Гају, а друга 1922. у Великом Гају. Обе су домаћице. У првом селу грађу су снимили колегиница Драгана Радовановић и аутор (2007), а у другом је то учинила студенткиња Лидија Гојков 1996. године у оквиру својих студијских обавеза. Њен акцентован транскрипт аутор је преслушао и кориговао на основу добро очуване магнетофонске траке.

Ираније је поређење различитих идиолеката из Србије и Румуније било предмет интересовања аутора овог рада (Бошњаковић 2014 и 2015). 
тискивања, што није био случај у МГ. Ареал овог наставка в. у: Ивић/Бошњаковић/Драгин 1997: 166-168.

1.2. Код глагола VI Белићеве врсте, чије смо примере забележили само у ВГ, чешћи је наставак -y (6 примера или 60\%) у односу на -ajy (4 примера или 40\%), док -ау није регистрован ниједном (зиду, иму; зидају). Слично је стање и у осталим српским банатским говорима са обе стране границе, с тим што је негде више пута чешћи наставак -ajy, а негде -y, док се аутентично дијалекатски облик - $a y$ јавља спорадично углавном у тамишкој зони (Ивић/Бошњаковић/Драгин 1997: 168-172; Бошњаковић/Вареника 2008: 268; Бошњаковић 2013: 83).

1.3. Код глагола VII и VIII врсте најчешће се јавља наставак $-y$, док се -е може срести у српском делу Баната, и то у Потисју (Ивић/Бошњаковић/ Драгин 1997: 172-175), али и у румунском: у Рудни (Бошњаковић/Вареника 2008: 268), у Ченеју (Бошњаковић 2013: 83). Међутим, наша грађа показује да је у ова два идиолекта само у употреби наставак $-y$, поред -дy, што је уочено и у неким другим говорима у румунском Банату (Бошњаковић/Првуловић 2012: 190): волу, носу, (МГ, 10х); заробу, праву, скупу (ВГ, 24x); држу (МГ,1х).

\section{Презент глагола типа добијем}

У банатским говорима шумадијско-војвођанског дијалекта презент глагола типа добим није уобичајен. Једино се јавио на крајњем југоистоку ове територије, у Иланџи, која се граничи са прелазним говорима према смедеревско-вршачком дијалекту. Тај тип презента, тј. прелазак глагола из IV у VII врсту, карактеристичан је за смедеревско-вршачке и косовско-ресавске говоре, али и за говор Радојева (Ивић/Бошњаковић/Драгин 1997: 226; Ивић 1958: 342). Међутим, ова појава се факултативно јавља и у неким српским говорима шумадијско-војвођанског дијалекта на територији румунског дела Баната, у Ченеју (Бошњаковић 2013: 90, Радовановић 2017: 353], али и у централним или прелазним говорима, Рудна (Бошњаковић/Вареника 2008: 270). Наша грађа показује да се у МГ та црта боље сачувала (83,33\%), а у ВГ је подједнак број примера типа добим и добијем: сваки доби, покрим, превим 2x, савим (МГ, 5x =83,33\%); сваки дан ти добим, доби шешир (ВГ, $2=50 \%)$; али и завијем (МГ, $1=16,67 \%)$; добију, да сашије (ВГ, $2=50 \%)$.

\section{Фymyp 1}

0. Српски говори у српском и румунском делу Баната познају неколико типова футура 1: сложен (ja ћу читати), прост (читаћу), аналитички (ja ћy да читам), балкански (ће да читам / ће чита), презент свршених глагола (прочитам).

1. Сложени футур преовлађује у банатским говорима шумадијско-војвођанског дијалекта на српској страни (Ивић/Бошњаковић/Драгин 1997: 181185), у српским поморишким говорима у Румунији (Бошњаковић/Првуловић 
2011: 191; Бошњаковић 2017: 37-39), у Ченеју код Темишвара и Плочици код Ковина (Бошњаковић 2015: 40-41). У нашој грађи он је забележен само у једном примеру и то у ВГ (Нећу ти купити више никад (ВГ, 7,14\%). Сличан футур има од XVI века и румунски језик, у којем се он гради од презента глагола a vrea 'хтети' (v)oi, (v)ei, (v)a, (v)om, (v)eți, (v)or и скраћеног инфинитива (face) (Испас 1984: 122; Демирај 1994: 126).

2. Аналитички футур је у српским говорима шумадијско-војвођанског дијалекта српског дела Баната много ређи од сложеног и простог, али није редак (Ивић/Бошњаковић/Драгин 1997: 181-185). Слично је и у поморишким говорима (Бошњаковић 2017: 39). У говору Банатских Хера инфинитив је замењен конструкцијом да + презент и у футуру 1 (Ивић 1958: 339). У говору Рудне он је потиснуо сложени футур (Бошњаковић/Вареника 2008: 269), а у идиолекту из Ченеја је чешћи него у идиолекту из Плочице (Бошњаковић 2015: 38-39). У нашој грађи у оба идиолекта аналитички футур се најчешће користи, при чему је забележено више примера у ВГ $(85,71 \%)$, а мање у МГ $(57,14 \%)$ :

(ВГ, 85,71\%) кобојаги ћу д идем на занат; то ћу после да посадим; са ћy и то да ти причам; а он виче: Мој Аца ће да те туче; ће да ми усеру муве (хаљину);

(МГ, 57,14\%) сутре ћу да правим; ће да уђе у пензији.

Овај тип футура је био и у румунском језику у XVI и XVII веку, али је од XVII века у употреби презент глагола a avea 'имати' am, ai, are, avem, aveți, au) и конјуктив презента [Eu am să cînt 'ја имам да певам'] (Испас, 1984: 123).

3. Балканским футуром можемо сматрати следеће моделе ћу читам и ће да читам. У првом случају имамо енклитику помоћног глагола, али уз презент се не јавља $\partial a$. У другом случају чува се конструкција да + презент, али је помоћни глагол сведен на партикулу ће. Први модел спомиње и Ивић за српске банатске говоре (1990: 196) и за говоре Банатских Хера (1958: 339), али и други истраживачи. Тако се први модел среће изузетно ретко и у српским поморишким говорима (Бошњаковић 2017: 40). Други модел је забележен само једном у идиолекту из Ченеја (Бошњаковић 2015: 39). У нашој грађи се срећу оба модела. Други и у МГ (и сад кажем: ће да кољем ) и у ВГ (а он каже: Ће да ти продам), а први само у МГ (ће дођеду деца у суботу), (МГ, $14,29 \%$ ВГ, 7,14\%).

У разговорном језику у јужној Румунији среће се слична конструкција као наш модел два: речца о $(<$ oa $<$ volet или $<$ au $<$ habunt $)$ и конјуктив презента (să cînt) ‘ће да певам’ (Асенова 2002: 207-208).

4. Свршени презент у значењу футура 1 се среће и у српском делу Баната, нарочито у селима уз румунску границу (Радојево, Српска Црња, Итебеј, Крушчица, али и у румунском делу, што се доводи у везу са интерференцијом са румунским језиком у којем се презент може употребити у функцији будућег времена (Ивић/Бошњаковић/Драгин, 1997: 372-373; Ивић 1958: 340). Када су поређени идиолекти Ченеја и Плочице (Бошњаковић 2015: 39-40), утврђено је да је свршени презент, нарочито гл. доћи, релативно чест на румунској страни (Ченеј), док се не јавља на српској (Плочица), што је овом 
приликом потврдила и наша анализа идиолеката МГ и ВГ: не ти купим машину, јел ти ниси ожењен [=нећу ти купити] (МГ, 14,29\%).

Дакле, у оба идиолекта футур 1 се најчешће (МГ, 57,14\% и ВГ, 85,71\%) гради помоћу енклитичких облика глагола хтети у презенту и кострукције да + презент. Ретки су примери с партикулом ће и да + презент (ће да кољем, МГ, $14,29 \%$ и ће да ти продам, ВГ, 7,14\%), са помоћним глаголом и презентом (ће дођеду деца у суботу, МГ, 14,29\%). Исто тако је ретка и употреба негираног футура типа (не ти купим машину, јел ти ниси ожењен [=нећу ти купити], МГ, 14,29\%) или са инфинитивом (Нећу ти купити више никад, ВГ, 7,14\%).

\section{Аналитизам у деклинациији}

1. Под утицајем румунског језика, чији је падежни систем једноставнији од српског ${ }^{4}$, у нашим говорима започет је процес аналитизације. На основу наше грађе видимо да је он присутнији у идиолекту из МГ: да иду с празне руке, не иду с празне руке; Једна машина је продо; сам морала по трипут, четир пут да станем до манастир да се одморим; сад нема те коние (МГ, 4x); ja сам имала пуно другарице; ранио и са детељине (ВГ, 2x). Аналитичке форме смо забележили и у говору Великог Семиклуша уз егзистенцијалне глаголе има и било (Бошњаковић и Првуловић 2012: 198), у Ченеју је уочено ширење номинатива, односно акузатива као општег падежа (Бошњаковић 2013: 86-87). Приликом поређења аналитизма у употреби падежа у идиолекту из Ченеја (Румунија) и Плочице (Србија), утврђено је да је он скоро непознат у другом говору, а да се у првом шири поље употребе акузатива и номинатива, али и предлошко-падежне конструкције (Бошњаковић 2014: 65-68)

2. Уместо присвојног придева (овчији сир) у МГ је чешћа употреба предлога од и генитива: сира од овце; са сиром од краве; метем ове лишће од вишье, лишће од целера, што је свакако настало под румунским утицајем. У румунском језику се од XVI века уместо посесивног генитива јавља аналитичка конструкција de + номинатив, односно акузатив (Асенова 2002: 80).

\section{Факултативна замена падежа правияа и места}

1. Још у време постојања синтетичке деклинације у балканским језицима је дошло до неразликовања падежа правца и места (Асенова 2002: 86). Тако се и у шумадијско-војвођанским говорима, нарочито на територији румунског дела Баната, падежи добро чувају на морфолошком, али не и на синтаксичком нивоу. Наиме, већина истраживача је забележила да се уз предлоге y, на, по мешају падежи правца и места: Веску 1958: 70-73; Живковић/Берић/Веску 1961: 80-81; Симић, Царан 2006: 152-158; Бошњаковић/Вареника 2008a: 273-274; Бошњаковић/Вареника 2009: 146-147; Бошњаковић/Радова-

\footnotetext{
${ }^{4}$ У румунском језику је дошло до синкретизма Н и А и Г и Д. Ови падежи се срећу само код чланованих именица у једнини и множини. Број падежних облика драстично је смањен код нечланованих именица м. р. и у множини (Асенова 2002: 77).
} 
новић 2009: 162; Бошњаковић/Првуловић 2012: 197; Бошњаковић 2013: 8388; Бошњаковић 2014: 61-64. Давно је уочено да се српски и хрватски говори у Румунији, с обзиром на употребу акузатива и локатива, деле у четири групе: а) у карашевским говорима чува се разлика између ова два падежа (Радан 2009: 297), б) у говорима клисурских села, Банатске Црне Горе, Рекаша и Кече акузатив је потиснуо употребу локатива, в) у северозападним банатским говорима у искључивој употреби је локатив, г) у средишњим говорима је слободна употреба ова два падежа.

2. Анализа нашег корпуса показује да идиолект из МГ у суштини припада четвртој групи говора у којој је слободна дистрибуција и акузатива и локатива. Ови падежи се употребљавају и правилно, при чему је већи број примера са локативом $(27,08 \%: 19,79 \%)$ :

a) Локатив (МГ, 26x, 27, 08\%, y, no): он је био у војски; румунски ће да научи у градиници; Слободан је служио у иркви; фифери су звали по селу; Свуд по соби то је било сламе метуто;

б) Акузатив (МГ, 19x, 19,79\%, y, на): ондак метем у лонац... метем $y$ лонце; ондак сам метла у флаше ... и метла опет у рерну; то жито се дигло на таван; смо мећали на астал сламе.

Код мешања ова два падежа опет је уочена превага примера замене акузатива локативом $(27,08 \%)$ у односу на замену локатива акузативом $(26,04 \%)$, што значи да је локатив у овом идиолекту и говору у благој предности $(54,16 \%)$ :

a) Акуз. > Лок. (МГ, 26x, 27,08\%, y, на): и отишо у војски; од ове сам метла у градини; кад смо морали да уђемо у задруги; сваке недеље сам ишла у иркви; и на слами метемо орасе; Ишла девојка на станиции пред њим;

б) Лок. > Акуз. (МГ, 25x, 26,04\%, y, на): и она је радила све у биров, ту у Темишвар је радила као на калкулатор; у Мали Гај било полак села Срби; је тамо био калуђер у манастир, у прву собу кад се уђе; по сто метара је било на таван жита; уп. и смо имали напоље градине.

3. У ВГ су такође забележени примери правилне употребе локатива $(11,94 \%)$ и акуазтива $(41,79 \%)$, при чему је више примера овог другог падежа:

а) Локатив (ВГ, $8 \mathrm{x}, 11,94 \%, y, н a)$ : он је учио за ковача у Вршиу; $у$ башти ми све никло; држимо на тавану;

б) Акузатив (ВГ, 28x, 41,79\%, y, на): да не би ишо у војску; ја сам ишла y школу; ложили у шпорет; Ишла сам у цркву; наишли на мину; идемо на кола; је дигла (слику) на таван.

Међутим, забележени су и примери замене локатива акузативом (40,30\%) и акузатива локативом $(5,97 \%)$, што нам показује да је акузатив у овом идиолекту и у говору у експанзији (82,09\%):

a) Лок. > Акуз. (ВГ, 27x, 40,30\%, y, на): y тај парк је био бунар; они држали штаб у једну велику кућу; су биле ту у иркву то, на то ве- 
черње; то си мого у папуче да идеш; на таван имам једну мустру; уп. и а напоље кречим ја сама;

б) Акуз. $>$ Лок. (ВГ, $4 \mathrm{x}, 5,97 \%, y, н а)$ : волела сам да идем код њи $y$ иркви што они сви поју заједно 5 ; Она се удала у Маргити; и то сам морала д идем у Маргити; овако је ишла на страни.

4. Интраговорничке варијације су присутне у оба идиолекта, при чему су оне чешће у МГ због утицаја румунског језика: ми смо имали млого фамилије у Панчеви и у Велики Гај, и у Вршаи, у Ватин, у Џаму (МГ); и то седу до јутри у шерпењу у води (МГ); више је радила напоље него у кућу, у кући је имала свекрву (ВГ).

Као и у ова два идиолекта слично стање је и у идиолектима Ченеја и Плочице. Говор Ченеја припада кикиндској говорној зони или северним говорима, те се у њему очекује само локатив, али је присутна и замена локатива акузативом, те је, по тој црти, сврстан у говоре са слободном дистрибуцијом ова два падежа. У Плочици је чешћа замена локатива акузативом, као и у ВГ (Бошњаковић 2014: 61-64).

5. Забележили смо и остале случајеве нарушавања употребе падежа правца и места. Тако се уместо код + генитив јавио датив (прилог): Сина сам га родила у болници у Дети, а девојку кући (МГ); Мита, он је био кући ... био је $к у \hbar и(В Г)$.

У МГ се уместо инструментала са предлогом под јавио акузатив (и тако је био не под пушку, него само тако на радњи метут), али и уместо акузатива употребљен је инструментал (Ишла девојка на станици пред юим).

\section{Удвојени објекти}

Удвајање или редупликација објекта је примарни или категоријални балканизам (Попов 1984: 41), који је најобичнији код личних заменица, и то у функцији индиректног објекта, а изузетно редак са именицама у српским народним говорима (Милорадовић 2009: 289-290). Удвајање личних заменица је забележено у југоисточном делу српског Баната и у Радојеву, али и у румунском (Ивић 1990: 196; Живковић/Берић/Веску 1961: 81; Бошњаковић/ Вареника 2009: 146; Бошњаковић/Првуловић 2012: 195). Овај процес шири се и на именице, што је забележено и у шумадијско-војвођанским говорима румунског дела Баната (Бошњаковић/Вареника 2008: 272; Бошњаковић 2013: 88), али и у Срему (Бошњаковић 2000: 67-71). У оба испитивана идиолекта забележени су примери удвојеног објекта:

\footnotetext{
${ }^{5}$ У разговорном језику често нема паузе између изговорених целина, а и оно о чему се размишља за наредни исказ ипак се реализује у текућем, што би могао бити случај и у овом примеру. Наиме, информаторка је кренула да прича како је волела да иде у швапску иркву, јер у иркви сви поје заједно.
} 
а) код личних заменица:

$\left.\mathrm{a}^{1}\right) \quad$ у дативу: Мене ми било жао да му не $м y^{6}$ дам кад је он све плако за мном (МГ);

$\left.\mathrm{a}^{2}\right)$ у акузативу: и та тетка га одржала њега, знаш (ВГ); И главно да смо га ми њега одатле донели са пустаре (ВГ);

б) али и код именица, и то обично у акузативу: Сина сам га родила у болници (МГ); Сваке године смо га клали, теоце $(\mathrm{MГ})$; краставце $u$ оперем лепо (МГ).

Реформулација исказа је условљена потребом његовог појашњења саговорнику, што се види из следећих примера који могу да указују и на пут настанка удвојеног објекта, нарочито када се прво јави енклитички облик заменице: било $u x$ раније лопова (ВГ); њина црква је била ту, швапска црква (ВГ); И главно да смо га ми њега одатле донели, са пустаре (ВГ).

Када говорник жели да вршиоца радње, носиоца својства или стања, контрастира, издвоји у односу на друге, може да употреби властито име и, након паузе, личну заменицу у анафорској служби: Мита, он је био кући ... био је кући [сви су били отерани, а он је остао код куће] (ВГ).

\section{Ред речи}

0. У оквиру реда речи анализираћемо: а) положај атрибута у именским синтагмама, б) положај енклитика и акцентованих речи уз негиране глаголе, в) положај глаголских и заменичких енклитика након реченичне паузе, тј. иза тачке и запете и иза везника $u$ и $a$.

1. Атрибути иза иеентра. Под утицајем румунског језика, у српским говорима у Румунији, али и у нашем делу Баната, у именским синтагмама атрибут може бити постпонован (Ивић/Бошњаковић/Драгин 1997: 402-403). Уочено је да је предикат обично у првом делу реченице, а да је тежиште информације на именици коју прати атрибут. У нашој грађи број примера са постпонованим атрибутом већи је у МГ него у ВГ (3:1), што сугерише да је румунски утицај ипак био пресудан за овај ред речи: и су га млели у каце велике, имамо каие велике; имам млого лоние велике; за тако свеце велике (МГ); вукли из Румуније циигљу печену ову да зидају (ВГ).

Устаљене синтагме имају уобичајен ред речи: бела лука (МГ).

2. Енклитике уз глаголску негаиију. Будући да негација у румунском (nu) носи акценат, и у говору Срба у Румунији она је увек акцентована, те не изненађују примери са енклитикама између негације и наглашеног глагола, што је у исто време и модел који постоји у румунском језику. Новина је да се између негације и глагола могу јавити и наглашене речи. У МГ је овакав ред

\footnotetext{
${ }^{6}$ Овде се јављају два енклитичка облика у дативу пошто је информаторка започела исказ уобичајеним редом енклитика уз негиран глагол (да му не дам), а потом наставила у духу румунског језика да не му дам).

${ }^{7}$ У разговорном језику се започета мисао мења и уместо објекта у једнини (теле), употребила је множину (теоце) јер се клање телади понављало сваке године.
} 
речи веома чест $(90,90 \%)$, а уобичајен веома редак $(9,09 \%)$ : Колач не се прави код нас, не се реже колач; не се покварено увати; тада не баш масти се је; ал не баш волу; и јел кад не маргарин истрејеш добро да је пена (МГ, 10х); али и да се не улепи (МГ, 1х).

У ВГ ред речи уз негацију није уопште нарушен: више уопште га не заливам; неко се не чешља; ја не волим тапете; показивали да не волу Србе (BГ, $4 \mathrm{x})$.

3. Енклитике иза запете или тачке. Проклитизација енклитика, настала под утицајем румунског језика, маркантна је црта српских говора у румунском делу Баната, али и у шумадијско-војвођанским говорима српског дела, и то у оним уз румунску границу (Живковић/Берић/Веску 1961: 81; Ивић/ Бошњаковић/Драгин 1997: 405-406; Бошњаковић/Вареника 2008: 272-273; Бошњаковић/Вареника 2009: 145; Бошњаковић/Првуловић 2012: 195; Бошњаковић 2013: 97-98; Младеновић/Радан 2013).

На самом почетку реченице или иза запете забележене су: енклитике помоћног глагола јесам (сам, cu, је, смо, cy), и хтети (ћy, ће), заменичко се у рефлексивним пасивним конструкцијама, заменичке енклитике у дативу (ми, $m u$, нам) и акузативу $(м е, 2 a, u)$. Грађа показује да је број примера са проклитизацијом скоро пет пута већи у МГ него у ВГ:

(МГ, 59 примера): Сам имала брата, сам имала оца, матер; ако је дошо неко у кући, cu му дао један колач; Слободан је служио у цркви, је био као црквењак; Смо имали млого земље; док ни се оженио, смо купили стан; који су имали децу, су отишли по вароши, су остали само они стари; и сад кажем: ће да кољем, ће дођеду деца у суботу; метем масти, се пржи маст, ... и ондак метем рен, се пржи малко у олај; нисам била, ми било хрђаво; ондак смо, нам извадили виноград...; трејем тако сас (маргарин), га праим као пену; кад је добро брашно, како треба, га мажем тако; $u$ (их) метли у бардаце;

(ВГ, 10 примера) онда био тамо пут, су могли с коли да; Па мани, мама, ћy ја на пролеће да кречим све; а он виче: Ће да ми избуши сву кућу; Има, једна је [удата] у Конак, ме нашла саде; а имала сам тог деду, ти кажем, што сам ти причала за овог; она упадне у бунар, се покваси; али и уобичајенији ред речи:

(ВГ) сено је купово, мислим, продаво се на излаз тамо; Добро, закоље се свиња доста; и то је мећала, мећала је краставце.

Код информатора су присутне интраговорничке варијације и у истој реченици: Смо имали кобилу, коње смо имали, смо имали краву, а смо продали је и... (МГ).

3. Енклитике иза везника. Углавном иза везника $u$, и ређе иза $a$, забележени су примери са глаголским (caм, cмо, cy) и заменичким енклитикама $(c e ;$ ми, нам, ме, га, нас). И овај положај енклитика познат је и у нашем делу Баната, посебно уз румунску границу, али и у српским говорима у Румунији (Ивић 1958: 345; Ивић/Бошњаковић/Драгин 1997: 404-405; Бошњаковић/Вареника 2008а: 273; Бошњаковић/Вареника 2009: 145; Бошњаковић/Првуловић 2012: 195; Бошњаковић 2013: 97-98; Младеновић/Радан 2013: 145). У МГ то је доследна појава, а у ВГ спорадична:

(МГ 34 примера) и сам опрала [воће] лепо, и сам и млела на машину од кобасице, и сам и метла; превим овако $u$ је савим одавде овако; тамо се венчала $и$ смо дали фруштук оде; па се водило, $а$ cy се научили и они сами да иду; $и$ cy ce дигли горе; $u$ се иде на 
гробље, $и$ се иде у цркви; метем у лонце $u$ ce кува, $а$ се кува млого да спадне да је густа; ја тако метем $u$ ми седу у две, три године; Је паметна $u$ нас слуша $u$ нам прави свашта; $u$ га уплетем лепо;

(ВГ 2 примера): И онда на послетку су отишли ту код чика Бранка неког, трговца и те тетка Лауре, $и$ су отишли код њи да види, да каже; Он ми стурио канте доле $u$ ме истуко $(\mathrm{B \Gamma}, 2 \mathrm{x})$.

Забележен је и један пример у којој је у саставној реченици изостао везник $u$ : дође попа (и) га очита, $2 x$.

\section{Закључак}

На основу детаљне анализе утврђено је да оба идиолекта имају исти инвентар дијалекатских особина карактеристичних за прелазне говоре на граници шумадијско-војвођанског и смедеревско-вршачког дијалекта, а да су разлике углавном квантитативне природе, настале након успостављања нове линије државне границе. У оба идиолекта (МГ1932 и ВГ1922) очувале су се неке црте у приближно истом обиму. Тако је најчешћа аналитичка творба футура 1 (ће да ми избуши сву кућу) и скоро доследна (поред -ду) употреба наставка -y у 3. л. мн. презента глагола VII и VIII Белићеве врсте (носу, држу).

Међутим, идиолект у МГ није био изложен утицају српског стандарда, те су у њему неке дијалекатске црте знатно фреквентније. Тако је употреба наставка -ду у 3. л. мн. презента свих глаголских врста знатно чешћа у МГ него у ВГ $(65,51 \%: 22 \%)$. Тај однос је још изразитији код употребе презента глагола типа добијем. У МГ облици добим : добијем стоје у односу 83,33\% : $16,67 \%$, а у ВГ $50 \%: 50 \%$.

Под утицајем румунског језика и његовог банатског дијалекта у идиолекту из МГ настале су нове црте које су веома фреквентне, а ретке на српској страни. Тако се аналитичке форме јављају у деклинацији (иду с празне руке; четир пут станем до манастир), али и у изражавању посесивности (сира од овце). У оба идиолекта, поред примера правилне употребе акузатива и локатива, дошло је и до њихове замене, при чему је у МГ употреба локатива у благој предности (54,16\%), а у ВГ акузатив је у експанзији $(82,09 \%)$. Удвојен објекат код личних заменица јавља се у оба идиолекта (Мене ми било жао; и та тетка га одржала њега), с тим што се у МГ јавља и са именицама (Сина сам га родила у болници). У МГ најизразитији је утицај у реду речи, како у синтагмама (имамо каце велике; не се види), тако и у реченици (Ће да ти продам; који су имали децу, су отишли по вароши, $c y$ остали само они стари; метем у лонац $и$ се кува, а се кува мало да спадне).

Дакле, морфолошке црте су стабилније јер су везане за српску лексику, док је ред речи под непрестаним утицајем реченичне структуре румунског језика будући да информаторка из МГ говори и румунски. 


\section{ЛИТЕРАТУРА}

Асенова 2002: П. Асенова, Балканско езикознание. Основни проблеми на Балканския съюз, В. Търново: Faber.

Бошњаковић 2000: Ж. Бошњаковић, О понављању реченичних конституената, Зборник Матице српске за филологију и лингвистику, XLIII, 65-72.

Бошњаковић/Вареника 2008а: Ж. Бошњаковић и С. Вареника, Напомене о морфосинтаксичким особинама српског говора села Рудне у Румунији, Сриски језик, 13, 261-279.

Бошњаковић/Радовановић 2009: Ж. Бошњаковић и Д. Радовановић, Теренски записи из Малог Гаја (Румунија), Прилози проучавағу језика 40, Нови Сад, 161-178.

Бошњаковић/Првуловић 2011: Ж. Бошњаковић и Т. Првуловић, Из говора села Семиклуша у Румунији, Темишварски зборник 6, Нови Сад, 179-206.

Бошњаковић 2013: Ж. Бошњаковић, Приватна писма као дијалекатски корпус: Дијалекатска скица говора Ченеја у Румунији, Зборник Матице српске за филологију и лингвистику, LVI/2, Нови Сад, 77-106.

Бошњаковић 2014: Ж. Бошњаковић, Једно поређење два српска идиолекта из Ченеја (код Темишвара) и Плочице (код Ковина), Sedmi međunarodni interdisciplinarni simpozijum Susret kultura, Zbornik radova, Univerzitet u Novom Sadu, Filozofski fakultet, Novi Sad, 59-70.

Бошњаковић 2015: Ж. Бошњаковић, Творба футура I у два писана идиолекта: из Ченеја (код Темишвара) и Плочице (код Ковина), Исходишта, 1, Савез Срба у Румунији, Центар за научна истраживања и културу Срба у Румунији - Филозофски факултет Универзитета у Нишу, Темишвар Ниш, 31-43.

Бошњаковић 2017: Ж. Бошњаковић, Творба футура I у српским поморишким говорима у Румунији, Исходишта, 3, Савез Срба у Румунији, Центар за научна истраживања и културу Срба у Румунији - Филозофски факултет Универзитета у Нишу, Филолошки, историјски и теолошки факултет Западног универзитета у Темишвару, Темишвар - Ниш, 33-44.

Веску 1958: В. Веску, Румынское влияние на синтаксис сребского диалекта в Банате, Romanoslavica, I, București, 70-73.

Демирај 1994: Ш. Демирај, Балканска лингвистика, Скопје: Библиотека Лингвистика.

Живковић/Берић/Веску 1961: М. Живковић, Б. Берић, В. Веску, О српским и хрватским говорима у румунском Банату, Нови живот, Темишвар, год. V, св. 2, 77-84.

Ивић 1958: П. Ивић, Место банатског херског говора међу српским дијалектима (Посебан отисак из зборника „Банатске Хере”), Нови Сад: Матица српска, 326-353.

Ивић 1990: П. Ивић, Балканизми у настајању у српским говорима Баната, у: О језику некадашњем и садашњем, Београд - Приштина, БИГЗ - Jединство, 189-198.

Ивић/Бошњаковић/ Драгин 1997: П. Ивић, Ж. Бошњаковић, Г. Драгин, Банатски говори шумадијско-војвођанског дијалекта, Друга књига: Мор- 
фологија, Синтакса, Закључци, Текстови, Српски дијалектолошки зборник, XLIII.

Испас 1984: Б. Испас, Учебник по румънски език, София: Издателство наука и изкуство.

Милорадовић 2009: С. Милорадовић, Статус објекатске редупликације у српским народним говорима, Годишњак за српски језик и књижевност Филозофског факултета у Нишу, 9, година XXII, 287-295.

Попов 1984: Б. Попов, Положај српскохрватског језика у балканском језичком савезу, Јужнословенски филолог, XL, 21-43.

Радан 2009: М. Радан, Иновације у српским говорима у румунском Банату у светлу језичке интерференције (са посебним освртом на карашевске говоре), Научни састанак слависта у Вукове дане, 38/1, 289-302.

Радовановић 2017: Д. Радовановић, Теренски записи из Ченеја, Исходии$m a, 3$, Савез Срба у Румунији, Центар за научна истраживања и културу Срба у Румунији - Филозофски факултет Универзитета у Нишу, Филолошки, историјски и теолошки факултет Западног универзитета у Темишвару, Темишвар - Ниш, 345-356.

Симић/Царан 2006: 3. Симић, М. Царан, О румунском утицају у говору Банатске Црне Горе, Probleme de filologie slavă, XIV, 151-163.

Томић 1968: М. Томић, Употреба акузатива и локатива у српским и хрватским говорима у Банату, Књижевни живот, Часопис Савеза књижевника Социјалистичке Републике Румуније, год. 1, св. 1, 86-88.

Žarko S. Bošnjaković

\section{MORPHOSYTACTIC SIMILARITIES AND DIFFERENCES IN TWO SERBIAN IDIOLEKTS FROM MALI GAJ (IN ROMANIA) AND VELIKI GAJ (IN SERBIA)}

Summary

The author, based on the analysis of the morphosyntactic characteristics (3rd person of present tense of the verb type dobijem; the construction of the future tense 1, analitism in the declination paradigm, the substitution of the direction and the place cases, the doubling of objects and the word order) in two idiolects (MG1932 and VG1922) of the transitional Šumadija-Vojvodina and Smederevo-Vršac speeches, determines the similarities and the differences that were created by the establishment of the state border (1918) between Mali Gaj (in Romania) and Veliki Gaj (in Serbia). The similarities are mainly reflected in the morphological level (the most common is the analytical futur 1; it is consistently used $-u$ in the case of VII and VIII verb types: nosu, $d r z ̌ u$ ). The differences are reduced mainly to a different frequency of some characteristics. Due to the absence of the influence of the Serbian standard in $\mathrm{MG}$, the dialect characteristics are more stable (-du; dobim). Due to regular communication in Romanian, in MG, Serbian syntactic models are mostly damaged (ne ti kupim mašinu, jel ti nisi oženjen [neću ti kupiti auto]; sad nema te konce; sira od ovce; sam išla u crkvi; ne se vidi; mene mi bilo žao; sina sam ga rodila; imamo kace velike; Će da ti prodam; koji su imali decu, su otišli po varoši, su ostali samo oni stari; metem u lonac $i$ se kuva, a se kuva malo da spadne).

Key words: dialectology, Šumadija-Vojvodina dialect, Smederevo-Vršac dialect, morphosintaxis, frequency index. 